
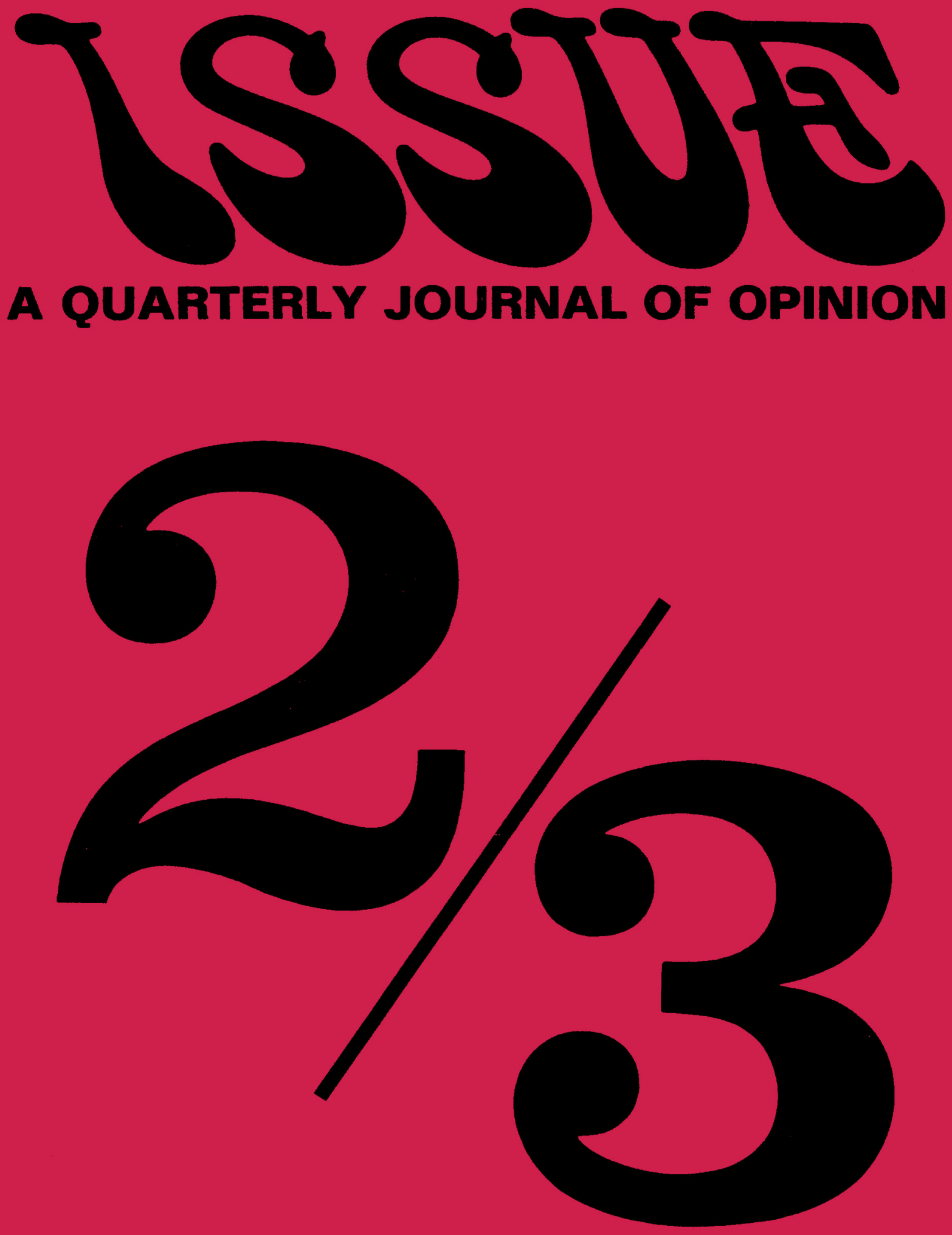

PUBLISHED BY THE AFRICAN STUDIES ASSOCIATION 
The essays in this special number of /ssue on African studies 1956-1976 were written at the invitation of the editor. I am indebted to each of the contributors for the cooperation which went into doing what we wanted done. The material has been printed as we received it, with little more than a light copyediting. There are a variety of opinions and memories, some which will not be agreeable to every eye. But the development of African studies in the United States in the last two decades has produced controversy, some of it bitter, and I have made no attempt to exclude or edit essays which record that controversy. Issue was created to be a journal of opinion.

I regret that the special edition is not as special as I hoped when we began. Significant by their absence are articles on "African Studies and United States Policies in Africa," a review of "Significant Books on Africa by American Scholars or Specialists," "The Views from Africa," and a survey on "Resources on Africa in American Libraries." In some cases I could not find a contributor; in others, the contributions did not materialize.

Although it is not the general policy in /ssue to publish letters and opinions, we will print a special section of responses to essays in this number, should they be forthcoming.

James Duffy

\section{NOTICE TO MEMBERS}

The Postal System does not forward periodicals. We must receive written notification from you at least five weeks in advance of any change of mailing address. Failure to notify us of your correct mailing address will result in suspension of your membership until we receive such notification. We can make address changes only when current dues are paid.

INFORMATION FOR CONTRIBUTORS TO ISSUE: Contributions are welcome. Manuscripts should be typed on one side of the sheet only, double-spaced, and with ample margins for editorial marking. The original and one carbon copy should be submitted. Authors are advised to include footnote material in the text wherever possible. Notes should be numbered consecutively and typed on a separate sheet after the text of the article. Maps and charts should be submitted as camera-ready copy. All editorial correspondence and manuscripts should be sent to: Editor, Issue, African Studies Association, 218 Shiffman Center, Brandeis University, Waltham, Massachusetts 02154. Domestic claims for non-receipt of issues must be made within six months of the month of publication; overseas claims, one year. Copies of Issue damaged in the mail will be replaced without charge. 


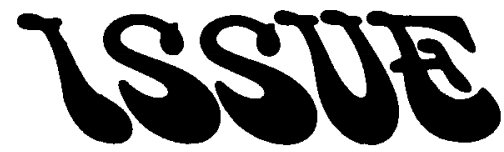

\section{A Quarterly Journal of Africanist Opinion}

VOLUME VI, NUMBERS $2 / 3$

SUMMER/FALL 1976

James Duffy, Editor

AFRICAN STUDIES 1955-1975

CONTENTS:

2

12

16

27

33

41

49

57

68

73

AFRICAN STUDIES IN THE UNITED STATES: 1955-1975

Gwendolen M. Carter

THE AFRICAN HERITAGE STUDIES ASSOCIATION (AHSA): SOME NOTES ON THE CONFLICT WITH THE AFRICAN STUDIES ASSOCIATION (ASA) AND THE FIGHT TO RECLAIM AFRICAN HISTORY John Henrik Clarke

2

MONTREAL IN 1969: A PERSONAL VIEW

Peter Gutkind

6 MEETING AFRICA'S CHALLENGE: THE STORY OF THE AMERICAN COMMITTEE ON AFRICA

George M. Houser

7 THE CONTRIBUTIONS OF AFRICAN SCHOLARS AND TEACHERS TO AFRICAN STUDIES, 1955-1975

Boniface I. Obichere

GOOD NEWS AND BAD NEWS: AFRICAN STUDIES IN AMERICAN SCHOOLS, 1955-1975

Evelyn Jones Rich

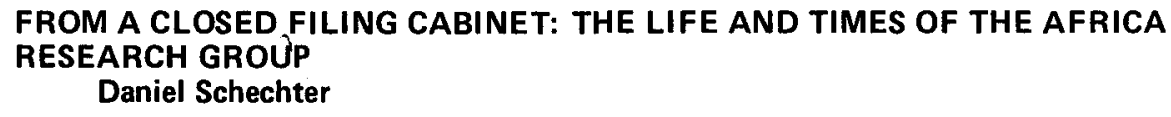

AFRICA AND THE UNITED STATES MEDIA Aaron Segal

AFRICAN STUDIES, 1955-1975: AN AFRO-AMERICAN PERSPECTIVE Elliott P. Skinner

THE FORD FOUNDATION AND AFRICAN STUDIES

Francis X. Suttion and David R. Smock

BLACK STUDIES AS AN INTEGRAL TRADITION IN AFRICAN-AMERICAN

INTELLECTUAL HISTORY

James Turner axd C. Steven McGann

Articles in Issue: A Quarterly Journal of Opinion represent neither the views of the African Studies Association nor those of its officers. The Editor is responsible for the final selection of the content of /ssue and reserves the right to reject any material deemed inappropriate for publication. Responsibility for opinions expressed and for the accuracy of facts published in articles rests solely with the individual authors. Responsibility for the copyediting of the material is also the author's.

Copyright (c) 1976 by the African Studies Association, Inc.

Any author has the right to republish his article in whole or in part without requesting permission from the Association. Others desiring permission to republish material should apply to the Editor. 